\title{
SUBSTITUSI FERMENTASI LIMBAH PADAT SURIMI IKAN SWANGGI (Priacanthus macracanthus) PADA TEPUNG IKAN TERHADAP RETENSI PROTEIN DAN RETENSI LEMAK IKAN LELE DUMBO (Clarias sp.)
}

\section{Substitution of Fermentation Waste Surimi Swanggi Fish (Priacanthus macracanthus) with Fish Meal on Protein Retention and Fat Retention Dumbo Catfish (Clarias sp.)}

\author{
Alif Aunurrofiq ${ }^{1}$, Prayogo ${ }^{2}$ dan Muhammad Arief ${ }^{2}$. \\ ${ }^{1}$ Program Studi Budidaya Perairan, Fakultas Perikanan dan Kelautan, Universitas Airlangga, Surabaya \\ ${ }^{2}$ Departemen Manajemen Kesehatan Ikan dan Budidaya Perairan, Fakultas Perikanan dan Kelautan, Universitas \\ Airlangga, Surabaya \\ Email : fpk@unair.ac.id
}

\begin{abstract}
Abstrak
Lele mudah beradaptasi dengan lingkungan air tawar. Prospek tersebut membuat ikan lele mendapat perhatian bagi pengusaha untuk mengelolanya. Pakan pada akuakultur berperan penting dalam menentukan keberhasilan perikanan dalam memenuhi kebutuhan ikan. Tingkat pertumbuhan ikan yang baik sangat bergantung pada formula pakan yang didasarkan pada kebutuhan ikan itu sendiri. Pemenuhan pakan ikan yang memiliki kandungan gizi sempurna hanya mengandalkan bahan pakan impor yang sangat mahal, oleh karena itu untuk mempercepat pertumbuhan dan menghemat biaya pakan diperlukan tambahan bahan pakan alternatif. Limbah padat Surimi terdiri dari kepala, kulit, duri dan tulang ikan. Perlakuan secara biologis yang dikenal dengan proses fermentasi adalah memanfaatkan kemajuan bioteknologi mikroba dan cara alternatif untuk mengoptimalkan daur ulang limbah perikanan. Prinsip kerja proses fermentasi yaitu memecah senyawa kompleks menjadi senyawa sederhana yang mudah dicerna oleh mikroorganisme. Penelitian ini menggunakan empat jenis perlakuan dengan lima ulangan pada masing-masing perlakuan. Substitusi fermentasi limbah padat ikan surimi swanggi pada P0, P1, P2 dan P3 adalah 0\%, 25\%, 50\% dan 75\%. Hasil penelitian menunjukkan bahwa substitusi fermentasi limbah padat surimi swanggi pada tepung ikan menunjukkan hasil yang tidak berbeda nyata $(p>0,05)$ pada retensi protein ikan dan menunjukkan hasil yang berbeda nyata $(p<0,05)$ terhadap retensi lemak ikan lele. Pemeliharaan kualitas air pada media ikan lele meliputi suhu $26-28{ }^{\circ} \mathrm{C}$, oksigen terlarut 5-8 mg / l, pH 7-8, dan amonia 0-1,5 mg / l.
\end{abstract}

Kata kunci: Ikan Lele, Limbah Padat Surimi, Retensi Protein dan Retensi Lemak

\begin{abstract}
Catfish easily adapt to freshwater environments. This prospect led to the catfish gets attention and is very attractive to entrepreneurs to cultivate them. Feed in aquaculture plays an important role in determining the success of fisheries and meet the needs of the fish. Good fish growth rate is highly dependent on feed formula which is based on the needs of the fish itself. Fulfillment of fish feed has the perfect nutrient content have only rely on imported feed ingredients are very expensive, therefore, to accelerate growth and save feed costs required the addition of alternative feed ingredients. Surimi solid waste consisting of head, skin, spines and fish bones. Biological treatment is known as the fermentation process is to utilize microbial biotechnology advances and an alternative way of optimizing the recycling of waste fisheries. The working principle of fermentation process that breaks down complex compounds into simpler compounds that are easily digested by microorganisms. This study uses four kinds of treatments with 5 replicates at each treatment. Where the substitution of solid waste fermentation surimi fish swanggi on P0, P1, P2 and P3 is 0\%, 25\%, 50\% and $75 \%$. Results of the research showed that the substitution of solid waste fermentation surimi swanggi in fishmeal showed results that were not significantly different $(\mathrm{p}>0.05)$ on protein retention catfish and showed results that were significantly different $(\mathrm{p}<0.05)$ on the retention of fatty fish catfish. Maintenance of water quality media catfish is 26-28 0C temperature, dissolved oxygen 5-8 mg / l, pH 7-8, Ammonia 0-1.5 mg / l.
\end{abstract}

Keywords: Catfish, Solid Waste Surimi, Protein Retention and Fat Retention 


\section{PENDAHULUAN}

Ikan lele merupakan jenis ikan konsumsi air tawar yang memiliki prospek cerah karena permintaan akan ikan lele untuk konsumsi termasuk tinggi dan harga jual yang cukup tinggi. Untuk membudidayakannya juga relatif mudah, karena ikan lele mudah beradaptasi dengan lingkungan perairan tawar. Prospek ini menyebabkan ikan lele mendapat perhatian dan sangat diminati para pengusaha untuk membudidayakannya.

Pakan dalam budidaya perikanan memegang peran penting dalam menentukan keberhasilan usaha perikanan dan memenuhi kebutuhan ikan (Nur dan Arifin, 2004). Karena harga pakan yang relatif mahal membuat pembudidaya ikan lele keberatan. Pengkajian lanjutan yang lebih intensif, khususnya bagaimana memanfaatkan bahan baku lokal yang tersedia dalam jumlah yang memadai sebagai bahan pakan harus dilakukan, guna menekan biaya pakan yang diperkirakan dapat mencapai sekitar 60-80\% dari total biaya produksi (Priyadi, 2008).

Bahan baku utama pada penyusunan ransum pakan ikan adalah tepung ikan, karena tepung ikan merupakan bahan baku utama sumber protein dalam pakan ikan. Namun, produksi tepung ikan lokal pada saat ini baru dapat memenuhi 60-70\% dari kebutuhan dengan kualitas dan kuantitas yang berfluktuatif. Oleh karena itu diperlukan penelitian yang mendalam terhadap berbagai bahan baku pengganti (substitusi) tepung ikan. Suatu bahan baku pakan dikatakan layak digunakan dalam pembuatan pakan ikan jika memenuhi persyaratan, antara lain mempunyai nilai gizi yang tinggi, tersedia dalam jumlah melimpah dan kontinyu serta secara ekonomi tidak menjadikan harga pakan tinggi (Mudjiman, 2004).

Limbah surimi adalah produk sisa dari pembuatan surimi ikan. Limbah surimi berbentuk padat yang terdiri dari kepala, kulit, duri dan tulang ikan. Pengolahan secara biologis dikenal sebagai proses fermentasi yang merupakan kemajuan bioteknologi dengan memanfaatkan mikroba dan merupakan cara alternatif optimalisasi daur ulang limbah perikanan (Muis dkk, 2008). Prinsip kerja proses fermentasi yaitu memecah senyawa yang kompleks menjadi senyawa sederhana yang mudah dicerna dengan bantuan mikroorganisme (Parakkasi, 1995).

Protein merupakan komponen penting karena zat tersebut mempunyai fungsi sebagai bahan-bahan dalam tubuh, serta sebagai zat pembangun, zat pengatur dan zat pembakar. Retensi protein merupakan jumlah (prosentase) protein yang diserap dan dimanfaatkan oleh tubuh ikan untuk membangun dan memperbaiki sel-sel tubuh yang rusak dan untuk metabolisme (Halver, 2002).

Lemak merupakan salah satu nutrien yang sangat dibutuhkan oleh ikan lele untuk hidup dan tumbuh. Lemak memiliki kandungan energi yang lebih besar dibandingkan karbohidrat dan protein. Ikan karnivora dapat mencerna dan memanfaatkan lemak lebih efisien dibanding ikan herbivora dan omnivora (Buwono, 2000). Lemak yang dibutuhkan ikan lele berkisar 9,5-10\% (Ghufran, 2008). Retensi lemak adalah gambaran dari banyaknya lemak yang berasal dari pakan yang diserap dan disimpan di dalam tubuh selama masa pemeliharaan (Syamsudin, dkk. 2010).

Penelitian ini bertujuan untuk memberikan informasi tentang tingkat subtitusi fermentasi limbah padat surimi ikan swanggi (Priacanthus macracanthus) pada tepung ikan yang dapat memberikan respon terbaik pada retensi protein dan retensi lemak ikan lele dumbo (Clarias sp.).

\section{METODOLOGI Waktu dan Tempat}

Penelitian ini dilaksanakan pada bulan September 2014 sampai Oktober 2014 di Fakultas Perikanan dan Kelautan, Universitas Airlangga. Analisa proksimat 
pakan ikan dilakukan di Laboratorium Kimia, Universitas Muhammadiyah Malang.

\section{Materi Penelitian}

Peralatan Penelitian

$$
\text { Dalam pembuatan pakan }
$$

dibutuhkan blender, timbangan listrik, mixer dan mesin pencetak pellet. Untuk pemeliharaan ikan antara lain akuarium, berukuran 30x20x20 cm3 sebanyak 20 buah, selang aerator, batu aerasi, $\mathrm{pH}$ meter, termometer, blower, plastik, karet gelang, pisau, ember plastik, penggaris dan timbangan digital.

\section{Bahan Penelitian}

Hewan uji berupa ikan lele dumbo (Clarias sp.) ukuran 5-7 cm sebanyak 140 ekor. Pellet buatan berupa tepung ikan, tepung bungkil kedelai, dedak halus, minyak ikan, multivitamin, dan tepung terigu. Tepung limbah ikan swanggi, limbah ikan swangi diperoleh dari PT. Starfood Internasional. Probiotik yang digunakan adalah probiotik komersil Raja Lele.

\section{Metode Penelitian}

Metode penelitian yang digunakan dalam penelitian ini adalah metode eksperimental yang terdiri dari empat perlakuan dengan lima ulangan. Kusriningrum (2008) menyatakan, eksperimen dapat didefinisikan sebagai suatu tindakan yang dibatasi dengan nyata dan dapat dianalisa hasilnya. Rancangan percobaan yang digunakan adalah Rancangan Acak Lengkap (RAL). Kusriningrum (2008) menyatakan bahwa rancangan acak lengkap dipergunakan apabila media, alat dan bahan percobaan seragam atau dapat dianggap seragam. Perlakuan yang digunakan dalam penelitian ini adalah sebagai berikut : $\mathrm{P}_{0}$ : pakan tanpa penambahan fermentasi limbah ikan swanggi; $\mathrm{P}_{1}$ : pakan dengan penambahan fermentasi limbah ikan swanggi sebanyak $25 \% ; \mathrm{P}_{2}$ : pakan dengan fermentasi penambahan limbah ikan swanggi sebanyak $50 \%$; $\mathrm{P}_{3}$ : pakan dengan penambahan fermentasi limbah ikan surimi sebanyak 75\%.

\section{Prosedur Kerja \\ Persiapan Pakan Ransum}

Limbah ikan swanggi dibersihkan selanjutnya dikeringkan dan digiling. Probiotik ditambahkan sebanyak 9\% (sesuai dengan penelitian Marera, 2014). Campuran tersebut diaduk 3-4 kali setiap hari selama empat hari, kemudian hari ke-5 sampai ke-7 diaduk satu kali sehari. Setelah itu dilakukan analisis proksimat. Diaplikasikan pada ikan lele sebagai pakan subtitusi untuk mengetahui Retensi Protein dan Retensi Lemak Ikan Lele.

\section{Pembuatan Pakan Perlakuan}

Bahan pakan diayak terlebih dahulu sehingga menghasilkan bahan yang lembut. Setelah semua bahan siap baru ditimbang sesuai dengan formulasi yang dikehendaki. Setelah ditimbang bahan yang berukuran mikro dicampur jadi satu sampai merata atau homogen, setelah itu baru yang ukuran makro dicampur ke dalam campuran mikro satu persatu sampai merata dalam wadah atau loyang. Bahan pakan yang telah tercampur merata dimasukan ke dalam loyang dan dikukus sampai 10 menit. Setelah adonan siap, kemudian dicetak dengan menggunakan mesin pellet atau mesin penggiling daging. Pellet yang sudah jadi kemudian dikeringkan dengan suhu 600C selama 24 jam dengan menggunakan oven, setelah di oven selama 24 jam pellet siap digunakan.

Cara pembuatan pakan lele pada setiap perlakuan sama dengan yang di atas. Pakan uji yang digunakan adalah pakan buatan berbentuk pellet kering yang ukurannya disesuaikan dengan ukuran bukaan mulut ikan. Komposisi pakan antar perlakuan dihitung dengan menggunakan metode gabungan trial dan bujur sangkar (Pearson). Pakan dengan jumlah hasil pemanfaatan limbah ikan swanggi dan tepung ikan yang berbeda-beda dalam ransum pakan diberikan pada tingkat 
pemberian 5\% dari biomassa (Suyanto, 2010).

\section{Persiapan Akuarium dan Air Media Pemeliharaan}

Akuarium yang akan digunakan berukuran (panjang $\mathrm{x}$ lebar $\mathrm{x}$ tinggi) 30x20x20 cm. Akuarium dibersihkan dan disterilisasi terlebih dahulu agar terhindar dari penyakit. Akuarium penelitian dicuci menggunakan sabun detergen dan dibilas sampai bersih selanjutnya bak dikeringkan. Media pemeliharaan adalah air tawar yang sebelumnya diaerasi selama satu hari. Air tersebut ditempatkan di dalam akuarium yang berjumlah 20 buah dan dilengkapi dengan aerator.

\section{Pemeliharaan Benih Ikan Lele Dumbo (Clarias Sp).}

Ikan uji yang digunakan pada penelitian ini adalah benih ikan Lele Dumbo (Clarias sp.). Ikan Lele dimasukkan dalam akuarium yang berukuran 30x20x20 cm dengan ketinggian air $12 \mathrm{~cm}$ yang berisi 7 liter air. Selama pemeliharaan, air diganti setiap tiga hari sekali sebanyak 50\% agar kualitas air tetap terjaga. Penyiponan kotoran sisa pakan dan feses dilakukan setiap tiga hari sekali di pagi hari. Pakan diberikan tiga kali dalam sehari pada jam 08.00, 12.00 dan 16.00 WIB (Honorius, 1996).

Jumlah pakan yang dikonsumsi dicatat setiap hari. Pakan percobaan diberikan selama 30 hari. Setiap 10 hari dilakukan penimbangan berat ikan. Sebelum penimbangan, ikan dipuasakan sehari sebelumnya dari setiap wadah akuarium percobaan. Parameter kualitas air yang diukur selama penelitian meliputi suhu, $\mathrm{pH}$ dan oksigen terlarut yang diukur setiap dua hari sekali.

\section{Pengambilan Data}

Pakan perlakuan dilakukan uji analisis proksimat kandungan lemak dan proteinnya sebanyak dua gram, serta ikan perlakuan diambil dagingnya sebanyak dua gram tiap perlakuan dan ulangan untuk dilakukan analisis proksimat retensi lemak dan retensi protein (Murtidjo, 2001). Analisis proksimat protein dan lemak daging lele dumbo dilakukan di awal dan akhir penelitian. Hasil analisis proksimat yang telah didapatkan dibandingkan, dianalisa dan di ambil kesimpulan penelitian.

\section{Manajemen Kualitas Air}

Pada proses pemeliharaan benih ikan lele dilakukan manajemen kualitas air, air diganti setiap tiga hari sekali sebanyak 50\% agar kualitas air tetap terjaga. Penyiponan kotoran sisa pakan dan feses dilakukan setiap tiga hari sekali di pagi hari. Pakan diberikan tiga kali dalam sehari pada jam 08.00, 12.00 dan 16.00 WIB (Honorius, 1996).

\section{Parameter Penelitian}

Parameter utama yang diamati adalah retensi protein dan retensi lemak ikan lele. Parameter penunjang pada penelitian ini yaitu suhu, $\mathrm{pH}$, DO dan ammonia.

\section{HASIL DAN PEMBAHASAN \\ Retensi Protein dan Retensi Lemak}

Dari hasil penelitian didapatkan nilai retensi protein yang teringgi pada perlakuan tiga $(33,979)$ dan yang terendah pada perlakuan nol $(33,458)$, serta nilai retensi lemak yang tertinggi yaitu pada perlakuan tiga $(14,493)$ dan yang terendah pada perlakuan nol (8,855).

\begin{tabular}{ccc}
\hline Perlakuan & Retensi Lemak (\%) \pm SD & Transformasi $\sqrt{\boldsymbol{y}} \pm$ SD \\
\hline $\mathrm{P}_{0}$ & $8,855^{\mathrm{d}} \pm 0,0185$ & $2,944 \pm 0,483$ \\
$\mathrm{P}_{1}$ & $12,368^{\mathrm{c}} \pm 0,0087$ & $3,512 \pm 0,192$ \\
$\mathrm{P}_{2}$ & $13,375^{\mathrm{b}} \pm 0,0073$ & $3,656 \pm 0,096$ \\
$\mathrm{P}_{3}$ & $14,493^{\mathrm{a}} \pm 0,028$ & $3,805 \pm 0,126$ \\
\hline
\end{tabular}




\begin{tabular}{cc}
\hline Perlakuan & Retensi Protein (\%) \pm SD \\
\hline $\mathrm{P}_{0}$ & $33,458 \pm 1,445$ \\
$\mathrm{P}_{1}$ & $33,591 \pm 0,806$ \\
$\mathrm{P}_{2}$ & $33,807 \pm 0,860$ \\
$\mathrm{P}_{3}$ & $33,979 \pm 0,278$ \\
\hline
\end{tabular}

Dari hasil analisa statistik menunjukkan bahwa substitusi limbah surimi swanggi pada pakan komersial menunjukkan hasil yang tidak berbeda nyata $(p>0,05)$ terhadap retensi protein ikan lele dan sangat berbeda nyata $(p<0,05)$ terhadap retensi lemak ikan lele.

\section{Kualitas Air}

Data nilai parameter kualitas air selama pemeliharaan ikan lele dumbo (Clarias sp.).

\begin{tabular}{lcccc}
\hline Parameter & $\mathrm{P}_{0}$ & $\mathrm{P}_{1}$ & $\mathrm{P}_{2}$ & $\mathrm{P}_{3}$ \\
\hline Suhu $\left({ }^{\circ} \mathrm{C}\right)$ & $26-28$ & $26-28$ & $26-28$ & $26-28$ \\
Oksigen Terlarut (mg/liter) & $5-8$ & $5-8$ & $5-8$ & $5-8$ \\
$\mathrm{Ph}$ & $7-8$ & $7-8$ & $7-8$ & $7-8$ \\
Amoniak (mg/liter) & $0-1,5$ & $0-1,5$ & $0-1,5$ & $0-1,5$ \\
\hline
\end{tabular}

Dari data diatas dapat disimpulkan bahwa kualitas air selama penelitian cukup optimal untuk pertumbuhan ikan lele dumbo (clarias sp.)

\section{Pembahasan \\ Retensi Protein}

Berdasarkan perhitungan data dapat dilihat bahwa nilai rata-rata retensi protein tertinggi didapat pada perlakuan P3 dengan perlakuan substitusi tepung ikan dengan fermentasi tepung limbah surimi ikan swanggi (Priacanthus macracanthus) sebanyak 30 \% yaitu sebesar 33,979\%. Berdasarkan analisa statistik menunjukkan bahwa substitusi tepung ikan dengan fermentasi limbah surimi ikan swanggi menunjukkan hasil yang tidak berbeda nyata $(p>0,05)$ terhadap retensi protein lele (Clarias sp). Hal tersebut menunjukkan bahwa fermentasi limbah surimi ikan swanggi dapat digunakan sebagai substitusi tepung ikan pada ransum. Hal ini diduga karena kadar protein limbah surimi ikan swanggi $(46,3137 \%)$ hampir sama dengan tepung ikan (47,8048\%).

$$
\text { Berdasarkan data penelitian }
$$

sebelumnya dapat dilihat bahwa pertumbuhan tertinggi ikan lele selama penelitian adalah 2,488\% (Entry, 2015). Pertumbuhan diasumsikan sebagai pertambahan jaringan struktural, yang berarti pertambahan jumlah protein dalam jaringan tubuh. Laju pertumbuhan ikan lele ditentukan oleh banyaknya protein yang dapat diserap oleh tubuh lele sebagai zat pembangun. Hampir semua jaringan secara aktif mengikat asam-asam amino dan menyimpannya secara intraseluler dalam konsentrasi yang lebih besar, untuk dibentuk menjadi protein tubuh (sel-sel tubuh) (Buwono, 2000).

Pemanfaatan dan penyerapan protein oleh jaringan tubuh akan meningkat secara efisien jika kadar lemak dalam ransum ditingkatkan dalam batas tertentu, nilai efisiensi protein akan tercapai secara optimal jika nilai protein dan lemak dalam ransum berturut-turut 25\% dan 18\% (Buwono, 2000).

\section{Retensi Lemak}

Berdasarkan analisa statistik menunjukkan bahwa substitusi tepung ikan dengan fermentasi limbah surimi ikan swanggi menunjukkan hasil yang sangat berbeda nyata $(p<0,01)$ terhadap retensi lemak lele (Clarias sp). 
Tubuh ikan membutuhkan lemak untuk disimpan sebagai lemak struktural. Untuk memenuhi kebutuhan lemak tersebut maka ikan mensintesis (biokonversi) lemak berasal dari nutrea non lemak, seperti karbohidrat menjadi asam-asam lemak dan trigliserida yang terjadi di hati dan jaringan lemak (Linder, 1992). Setelah kebutuhan protein terpenuhi dan kebutuhan energi tercukupi maka lemak dari pakan akan disimpan dalam jaringan ikan.

\section{Kualitas Air}

Air merupakan faktor penting dalam kegiatan pemeliharaan ikan lele dan semua biota akuatik lainnya, maka dari itu media untuk tumbuh dan berkembang ini haruslah memiliki kualitas yang baik agar kegiatan budidaya dapat berjalan dengan lancar dan sesuai dengan apa yang diharapkan (Suyanto, 2004). Beberapa parameter utama kualitas air yang diukur dalam penelitian ini yaitu suhu, oksigen terlarut (DO), $\mathrm{pH}$, dan amonia.

Nilai kisaran suhu air penelitian berkisar antara $26-28{ }^{\circ} \mathrm{C}$. Hal ini masih kurang optimal karena suhu ideal untuk pertumbuhan lele berkisar antara $28-32{ }^{\circ} \mathrm{C}$ jika mengacu pada pendapat Suyanto (2004). Suhu tersebut terjadi diduga karena wadah pemeliharaan yang menggunakan akuarium.

Oksigen terlarut adalah jumlah gas oksigen dalam mg/l yang terlarut dalam air. Oksigen terlarut dibutuhkan oleh semua organisme untuk pernafasan, proses metabolisme atau pertukaran zat yang kemudian menghasilkan energi untuk pertumbuhan dan perkembangbiakan juga untuk oksidasi bahan-bahan organik dan anorganik dalam proses aerobik (Kordi dan Tancung, 2007). Hasil pengukuran Dissolved Oxygen (DO) atau oksigen terlarut selama penelitian berkisar antara 5-8 mg/l. Khairuman (2008) menyatakan bahwa kandungan oksigen terlarut yang baik untuk pertumbuhan ikan lele adalah sebesr $>3 \mathrm{mg} / \mathrm{l}$. Dari hasil tersebut dapat disimpulkan bahwa kadar oksigen terlarut dalam air selama penelitian sangat optimal.

Hasil pengukuran nilai $\mathrm{pH}$ selama penelitian berkisar 7-8. Hal ini sesuai dengan pendapat khairuman (2008) yang menyatakan nilai $\mathrm{pH}$ optimal untuk budidaya ikan lele antara 6,5-8. Derajat keasaman $(\mathrm{pH})$ adalah suatu kondisi ion hidrogen dan menunjukkan air tersebut bersifat asam atau basa. Secara alamiah $\mathrm{pH}$ perairan dipengaruhi oleh konsentrasi karbondioksida (CO2) dan senyawa yang bersifat asam. Selama proses fotosintesis tanaman air dan fitoplankton akan mengambil karbondioksida dari air sehingga mengakibatkan $\mathrm{pH}$ air rendah pada pagi hari, meningkat pada siang hari dan mencapai maksimum pada sore hari, selanjutnya akan menurun pada malam hari (Mulyanto, 1992).

Dalam budidaya ikan, sisa pakan dalam bentuk feses atau yang tidak termakan berperan besar dalam penurunan kualitas air, ditandai dengan kandungan amonia yang tinggi. Amonia yang tidak terionisasi memiliki pengaruh meracuni bagi ikan (Kordi dan Tanjung, 2007). Konsentrasi amonia pada air pemeliharaan benih ikan lele penelitian berkisar antara 01,5 mg/l. Menurut effendi (2003) konsentrasi amonia total yang dapat diterima oleh ikan lele berada dibawah 0,2 $\mathrm{mg} / \mathrm{l}$. Kadar amonia yang terlalu tinggi dapat menghambat pertumbuhan dan dalam jangka panjang dapat menyebabkan kematian. Kadar amonia yang tinggi dapat diatasi dengan penyifonan dan penggantian air.

\section{KESIMPULAN DAN SARAN Kesimpulan}

Berdasarkan hasil penelitian yang dilakukan, dapat diambil kesimpulan bahwa substitusi limbah padat surimi ikan swanggi pada tepung ikan tidak berpengaruh terhadap retensi protein ikan lele (Clarias sp) dan sangat berpengaruh terhadap retensi lemak ikan lele (Clarias sp.). 


\section{Saran}

Berdasarkan hasil penelitian yang telah dilakukan, fermentasi limbah padat surimi dapat dipakai sebagai pengganti tepung ikan dalam ransum pakan ikan lele.

\section{DAFTAR PUSTAKA}

Abidin Nur, Zaenal Arifin. 2004. Nutrisi dan Formulasi Pakan Ikan. Departemen Kelautan dan Perikanan. Balai Besar Pengembangan Budidaya Air Payau Jepara. Jepara.

Afrianto, E dan E. Liviawati. 2005. Pakan Ikan. Kanisius. Yogyakarta. hal 1824.

Agustono., H. Setyono, T. Nurhajati, M. Lamid, M. A. Al-Arief, W. P. Lokapirnasari. 2011a. Petunjuk Praktikum Nutrisi Ikan. Fakultas Perikanan dan Kelautan. Universitas Airlangga. Surabaya. hal 23.

Agustono, H. Setyono, T. Nurhajati, M. Lamid, M. A. Al-Arief, W. P. Lokapirnasari. 2011a. Petunjuk Praktikum Nutrisi Ikan. Fakultas Perikanan dan Kelautan. Universitas Airlangga. Surabaya. hal 3, 7.

Budianto A.K., 2009. Pangan, Gizi, dan Pembangunan Manusia Indonesia: Dasar-Dasar Ilmu Gizi. Malang: UMM Press 1-6.

Boyd, C. E. 1982. Water Quality Management for Pond Fish Culture. Amsterdam : Elsevier Scientific Publ. P:319.

Buwono, I.D. 2000. Kebutuhan Asam Amino Esensial Dalam Ransum Ikan. Kanisius. Yogyakarta. hal. 11, 12, 13, 17, 18, 30.

Djarijah, A. S. 1995. Pakan Ikan Alami. Kanisius. Yogyakarta.

Djatmika, D.H., Farlina, Suguharti, E. 1986. Usaha Budidaya Ikan Lele.

C.V. Simplex. Jakarta.
Ghufran H. Kordi K., 2008. Budidaya Perairan. PT. Citra Aditya. Bandung.

Hariati, A.M. 1989. Makanan Ikan. LUW/UNIBRAW/Fish Fisheries Project Malang. 99 hal.

Harsono Puspowardoyo. 2002. Pembenihan dan Pembesaran Lele Dumbo Hemat Air. Yogyakarta.

Halver, J.E. and Hardy. 2002. Fish Nutrition. Third Edition. California USA. Academy Press inc. 822 pp. P: 712-713.

Irianto, Kus. 2007. Gizi dan Pola Hidup Sehat. Yrama Widya. Bandung.

Kumar Et Al. 2008. Biosorption Of Chromium (VI) From Aqueous Solution and Electroplating Wastewater Using Fungal Biomass. Chemical Enginering Journal vol. 135, hal. 202-208.

Kusriningrum, R. S. 2012. Perancangan Percobaan. Airlangga University Press. Surabaya. hal 43-63.

Khairuman dan K. Amri. 2011. Buku Pintar Budidaya dan Bisnis 15 Ikan Konsumsi. Agromedia Pustaka. Jakarta.

Lesmana, E. 2015. Pemberian Pakan dengan Substitusi Fermentasi Limbah Padat Surimi Ikan Swanggi (Priacanthus macracanthus) dalam Ransum Pakan sebagai Substitusi Tepung Ikan Terhadap Laju Pertumbuhan Harian dan Efisiensi Pakan Ikan lele (Clarias sp.). Skripsi. Fakultas Perikanan dan Kelautan. Universitas Airlangga. Surabaya.

Lovell, T. 1989. Nutrition and Feeding of Fish. Auburn University. New York. 217 hal.

Mudjiman, A. 2004. Makanan Ikan. Penebar Swadaya. Jakarta. 190 hal.

Muis, A, Khairani, C, Sukarjo, Rahardjo,Y.P. 2008. Petunjuk Teknis Teknologi Pendukung Pengembangan Agribisnis di Desa P4MI. Badan Penelitian Dan Pengambangan Pertanian. Balai 
Pengkajian Teknologi Pertanian. Sulawesi Tengah.

Mulyanto. 1992. Lingkungan Hidup Untuk Ikan. Departemen Pendidikan dan Kebudayaan. Jakarta.

Nurilmala, M. 2004. Kajian Potensi Limbah Tulang Ikan Keras (Teleostei) sebagai Sumber Gelatin dan Analisis Karakteristiknya. Institut Pertanian Bogor. Bogor. hal 5-42.

Oktaviana T.D., Aptika. 2009. Analisa Pengolahan Limbah Lateks Menjadi Biogas di PT. Perkebunan Nusantara IX (PERSERO) Kerjoarum Karanganyar Jawa Tengah. Surakarta : Universitas Sebelas Maret.

Parakkasi, A., 1995. Ilmu Nutrisi Ruminansia Pedaging. Departemen Ilmu Pakan Ternak, Fakultas Pertanian, IPB Bogor.

Park JW dan Morrissey MT. 2000. Manufacturing of surimi from light muscle fish. Dalam: Park JW (eds). Surimi and Surimi Seafood. New York: Marcel Dekker, Inc. pp. 2358.

Priyadi, A., Azwar, Z. I., Subamia, I.W., dan Hem, S. 2008. Pemanfaatan Maggot Sebagai Pengganti Tepung Ikan Dalam Pakan Buatan Untuk Benih Ikan Balashark (Balanthiocheilus Melanopterus Bleeker).

Rahman, A. 1992. Teknologi Fermentasi. Arcan. Jakarta.

Rengpipat S, Rukpratanporn S, Piyatitivorakul S, Menasaveta P. 2000. Immunity Enhancement in Black Tiger Shrimp (Panaeus Monodon) by a Probiont Bacterium (Bacillus S 11). Aquaculture 191:271-288.

Rustidja, 1997. Kebutuhan Makan Benih Ikan Lele Clarias bathracus. Tesis Program Pasca Sarjana. Fakultas Perikanan IPB. Bogor.
Santoso, B. 1994. Petunjuk Praktis Budidaya Lele Dumbo dan Lokal. Kanisius. Jakarta.

Suharto. 2010. Limbah Kimia dalam Pencemaran Air dan Udara. Andi. Yogyakarta.

Suparjo. 2010. Analisis Bahan Pakan Secara Kimiawi:Analisis Proksimat dan Analisis Serat. Laboratorium Makanan Ternak. Fakultas Peternakan. Universitas Jambi. Jambi.

Syamsuddin, R. 2010. Sektor Perikanan Kawasan Indonesia Timur: Potensi, Permasalahan, dan Prospek. PT Perca. Jakarta.

Watanabe, T., M.J. Lee, J. Mitzutani, T. Yamada, S. Satoh, T Taeuchi, N. Yossida, T. Kitada and T. Arakawa. 1991. Effective Components in Cuttlefish Meal and Raw Krill for Improvement of Quality of Red Sea Bream Pagrus Major Eggs. Bull. Jpn. Soc. Sci. Fish. pp. 681-694. 